\title{
Preliminary Estimation of Snow Covers Extents of Astore River Basin in Northern Areas, Pakistan
}

\author{
Anam Ashraf ${ }^{1}$, Sheikh Saeed Ahmad ${ }^{1}$, Neelam Aziz ${ }^{1} \&$ Muhammad Tahir Ali Shah ${ }^{2}$ \\ ${ }^{1}$ Department of Environmental Sciences, Fatima Jinnah Women University, Rawalpindi, Pakistan \\ ${ }^{2}$ Department of Agriculture, Allama Iqbal Open University, Islamabad, Pakistan \\ Correspondence: Sheikh Saeed Ahmad, Department of Environmental Sciences, Fatima Jinnah Women \\ University, Rawalpindi, Pakistan. Tel: 92-321-516-7726. E-mail: drsaeed@fjwu.edu.pk
}

Received: April 21, 2012 Accepted: May 2, 2012 Online Published: May 22, 2012

doi:10.5539/jgg.v4n2p124 URL: http://dx.doi.org/10.5539/jgg.v4n2p124

\begin{abstract}
An assessment of snow accumulation and depletion is necessary for the management of water resources in the region, where a great portion of annual precipitation falls in form of snow. This study was done to estimate the snow covered area of Northern Areas (Astore) in snow accumulation and snow ablation period with the aid of remote sensing (RS) techniques. Satellite image of Moderate Resolution Imaging Spectroradiometer (MODIS) was used to evaluate snow cover and classify the behavior of different image pixels in snow covered, partially covered and snow free pixels respectively. In order to nullify the obstruction offered by clouds only one cloud free image per week was selected for the years of 2008-2009 and data was analyzed using different ArcGIS and ERDAS Imagine tools. Watershed area of Astore river basin was calculated by using Digital Elevation Model. Normalized Differential Snow Index (NDSI) was used to draw snow cover map. Snow covered area was calculated in square kilometer and curves of snow cover extents were made for both years separately. Furthermore correlation curves were made for snow cover fluctuation with varying precipitation, minimum temperature and maximum temperature for years of 2008-2009. The observed correlation coefficient between snow cover, maximum temperature, minimum temperature and precipitation was found to be $-0.784(0.003)$, $-0.767(0.004), 0.561(0.058)$ respectively for both the years. Moreover multiple linear regression equation was generated for future snow cover prediction under different climatic scenarios. January and February was found to be snow accumulation period and for May, July, June it was snow ablation period for both years.
\end{abstract}

Keywords: snow cover, Astore river basin, meteorological parameters, Moderate Resolution Imaging Spectroradiometer (MODIS), Normalized Differential Snow Index (NDSI), Digital Elevation Model (DEM)

\section{Introduction}

Pakistan has a variety of climatic regime varying from hot deserts to cold snow covered areas. The Northern Areas of Pakistan have cold climate, in winters due to western depression yields snow over Himalaya-Karakorum-Hindukush (HKH). In summers the accumulated snow melts to recharge Himalayan river system. This runoff water is accumulated in water reservoirs for irrigation and hydro power production. Generation of runoff water provide millions of people living in mountainous regions with fresh water (Dahri, Ahmad, Leach, \& Ahmad, 2011).

Snow falls in the months of September - February and melts in the moths of March - August in Northern Areas of Pakistan. Frozen snow and glaciated ice in the mountainous Northern regions of Pakistan serves as its reserved hydrological resource. Conventional techniques for the measurement of snow coverextents are challenging and time consuming. More over these areas of Pakistan are difficult to access as they have varying topography and terrain. Nowadays remote sensing (RS) is proved to be a feasible tool to study snow covered areas.

Moderate Resolution Imaging Spectroradiometer (MODIS), aboard terra spacecraft of Earth Observing Systems (EOS) is being very handy for the estimation of Normalized Differential Snow Index (NDSI). Snow cover is highly influenced by changing climate and meteorological parameters. Snow falling and melting both are greatly influenced by daily minimum and maximum temperatures (Rasul, Chudhry, Mahmood, Hyder, \& Dahe, 2011). Numerous researches were done on snow cover extent of other districts of Northern Areas but Astore 
wasremaining neglected. Therefore this study was designed to analyze the impacts of meteorological parameters on the snow cover of Northern Area, Astore. Basic aim of this study was to find out the spatio-temporal distribution of snow cover of Astore river basin for the period of 2008-2009. Additionally to evaluate the effect of meteorological variables on snow cover distribution. Snow cover is the visible indicator of changing climate, snow cover extent and snow melt runoff are some of the major parameters directly related to the climatic changes. Hence this study signifies the effects of changing climatic conditions on the behavior of snow cover extent of Astore river basin.

\section{Study Area}

Astore river basin (Figure 1) is located in the high mountains of HKH region with snow peaks exceeding 7000m in height. This area is mostly covered by perennial snow and ice (Akhtar, Ahmad, \&Booij, 2008). The geographic location of Astore is $34^{\circ}, 45^{\prime}$ to $35^{\circ}, 38^{\prime} \mathrm{N}$ latitude and $74^{\circ}, 24^{\prime}$ to $75^{\circ}, 14^{\prime}$ E longitude. Elevation varies from $1,200 \mathrm{~m}$ to $7,500 \mathrm{~m}$ above mean sea level. The total catchment area is $4,214 \mathrm{~km}_{2}$ with $607 \mathrm{~km}^{2}$ glaciated area (Nabi, Latif, Habib-ur-Rehman, \& Azhar, 2011). Glaciers are mainly nourished by westerly disturbance (Hewitt, Wake, Young, \& David, 1989) According to SHIP (Snow and Ice Hydrology Project, 1990) $80-90 \%$ of the area gets covered by snow, seasonal melting of snow and glaciers ice both are large contributor of discharge water in summer season.

\section{Astore River Basin Catchment}

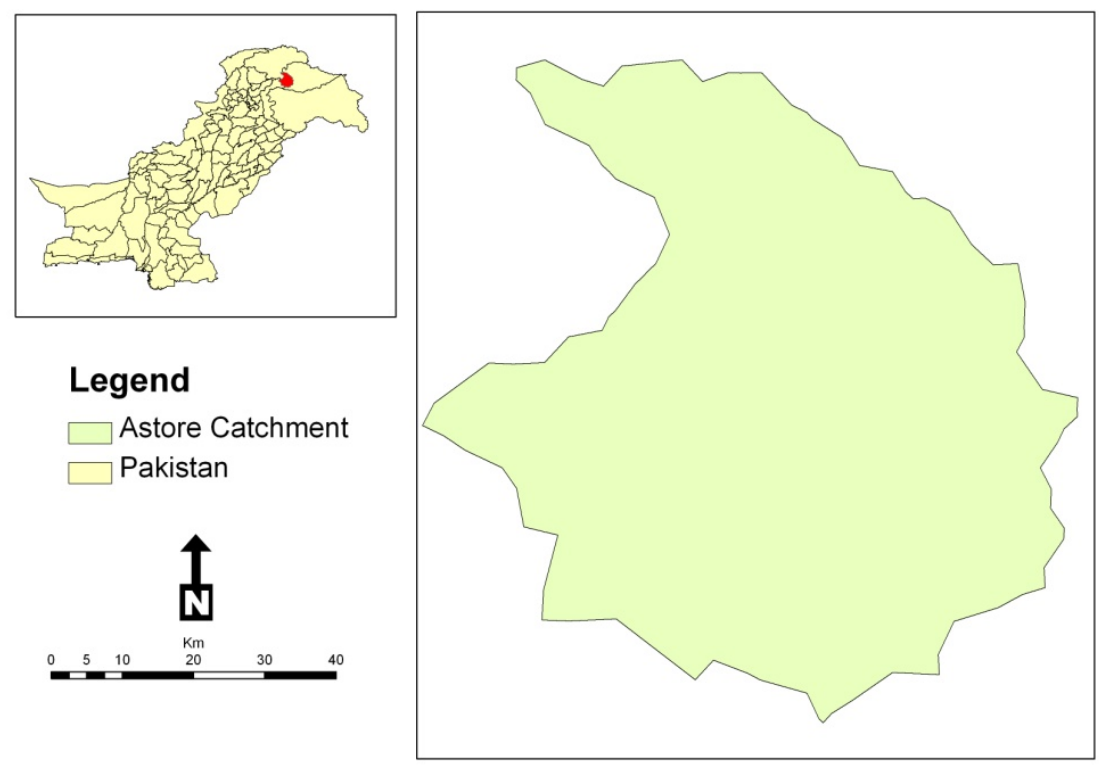

Figure 1. Base map of the study area (Astore river basin)

\section{Material and Methods}

\subsection{Data Acquisition}

Moderate Resolution Imaging Spectroradiometer (MODIS) snow product was utilized to estimate the snow cover of the study area. Satellite images for snow cover L3 Global 500m Grid (MOD10A2) at 250mfrom MODIS/Terra was acquired (Hall, Riggs, \& Salomonson, 1995). Cloud free images (Figure 2) from the period of January, 2008 to December, 2009 were downloaded from http://ladsweb.nascom.nasa.gov/data/search.htm. The MODIS snow cover algorithm works on the principle of high reflectance of snow in visible band 6 and band 4, likewise these two bands are used to calculate NDSI (Lopez, Sirguey, Arnaud, Pouyaud, \& Chevallier, 2008). Data for daily precipitation, maximum temperature and minimum temperature over the period of 2008-2009 of Astore station was provided by Pakistan Meteorological Department. 


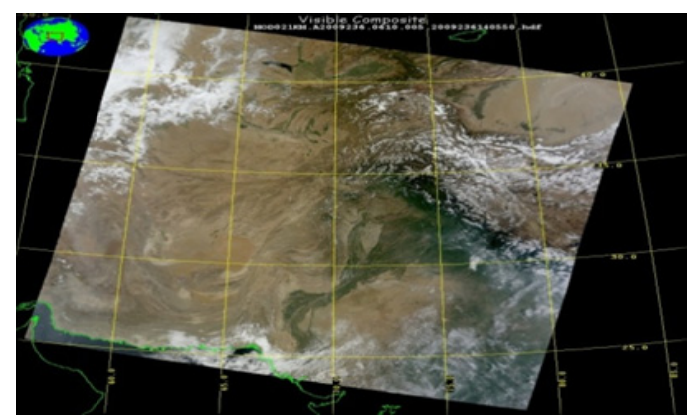

Figure 2. Example of MODIS image (22 ${ }^{\text {nd }}$ Aug, 2009) covering Pakistan

\subsection{Snow Cover Estimation}

The available cloud free MODIS images from January 2008-December 2009 on 8 day classification were collected and mosaicked. The mosaicked images were rectified against a pre-rectified image. The Astore river basin was extracted from the mosaicked images. Before this extraction of Astore, its watershed area for basin was calculated by using Digital Elevations Model (DEM). The visible band (band 4 with wavelength $0.545-0.565 \mu \mathrm{m}$ ) and near infrared band (band 6 with wavelength 1.628-1.652 $\mu \mathrm{m}$ ) of MODIS were used to calculate NDSI (Figure 3) (Furrukh \& Ghulam, 2010).

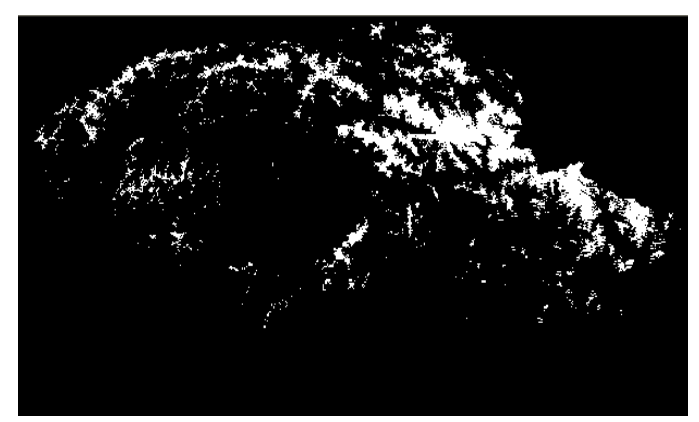

Figure 3. Snow covered area $\left(10^{\text {th }}\right.$ Oct, 2009) in Northern Areas

Mathematical expression of Normalized Differential Snow Index (NDSI) is as follows:

$$
\text { NDSI }=\left(\text { MODIS }_{\text {BAND4 }}-\text { MODIS }_{\text {BAND6 }}\right) /\left(\text { MODIS }_{\text {BAND4 }}+\text { MODIS }_{\text {BAND } 6}\right)
$$

MODIS image pixel value greater or equal to 0.4 is considered as snow coved pixel (Hall, Riggs, \&Salomonson, 1995).The maximum and minimum temperature values were taken out for the day for which NDSI was calculated from daily meteorological data (Astore station). Furthermore, different Correlation graphs were made to evaluate the effect of meteorological parameters on the snow covered area of study area.

\section{Results and Discussion}

NDSI was calculated and graphs were plotted for both the years. Correlation coefficient between NDSI and different climatic variable (maximum andminimum temperature and precipitation) were calculated for the study area. A highly significant correlation was found between NDSI and climatic variables.

\subsection{Snow Cover}

MODIS image analysis was done to evaluate snow area extents. For Presence of snow with NDSI as given in Equation 1, only the pixel with value greater than or equal to 0.4 was considered as snow. NDSI was calculated for 2008 and 2009 and plotted separately (Figures 4 and 5). 


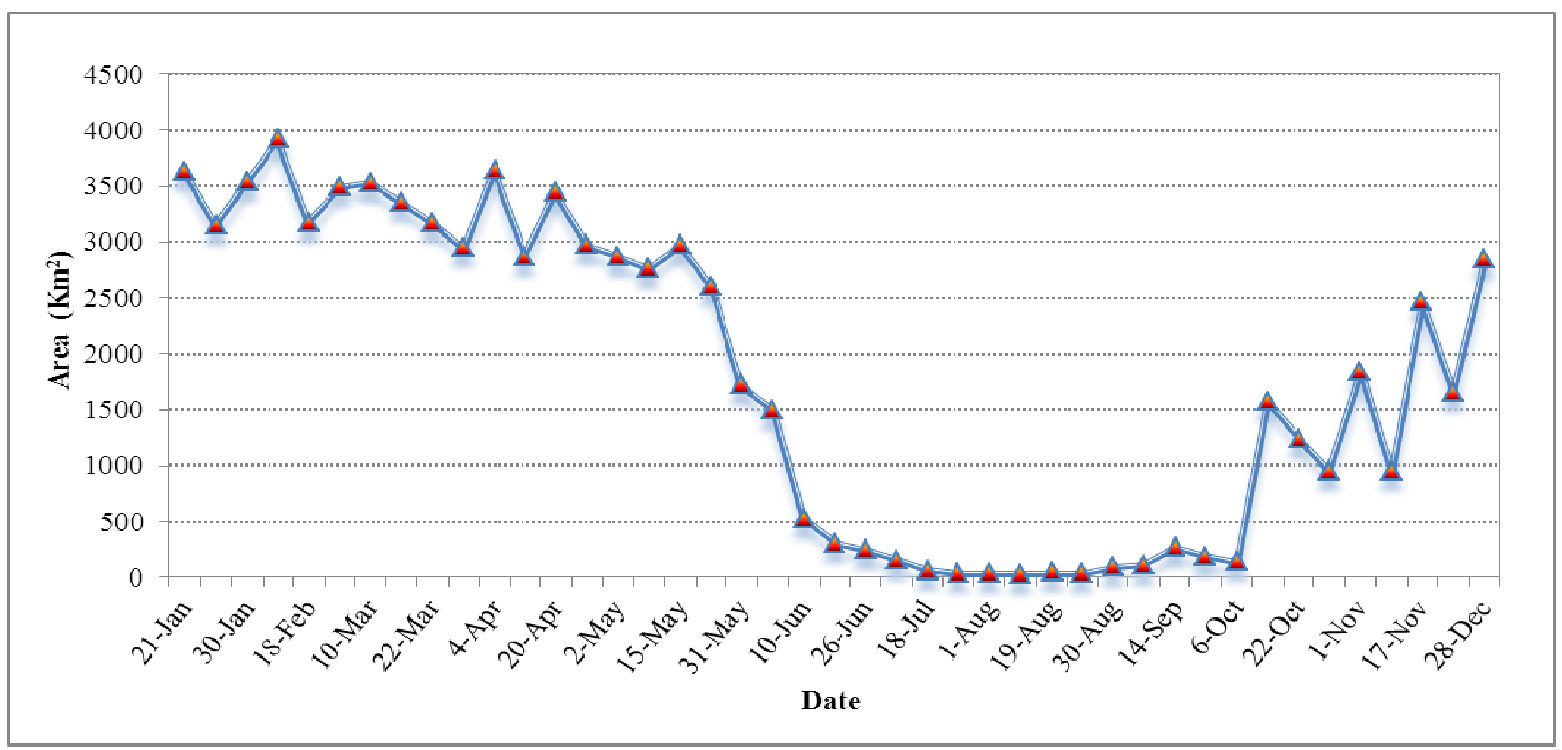

Figure 4. Snow cover extent of Astore River Basin in year 2008

The maximum snow cover observed for the year 2008 using NDSI model was $3630.70 \mathrm{Km}^{2}$ (16801 pixels) and $3920.49 \mathrm{Km}^{2}$ (18142 pixels) for the month of January and February. Whilst the minimum snow covered was found in the months of June, July, August and September. Least snow covered area was found for the month of August which was $30.25 \mathrm{Km}^{2}$ (140 pixels).

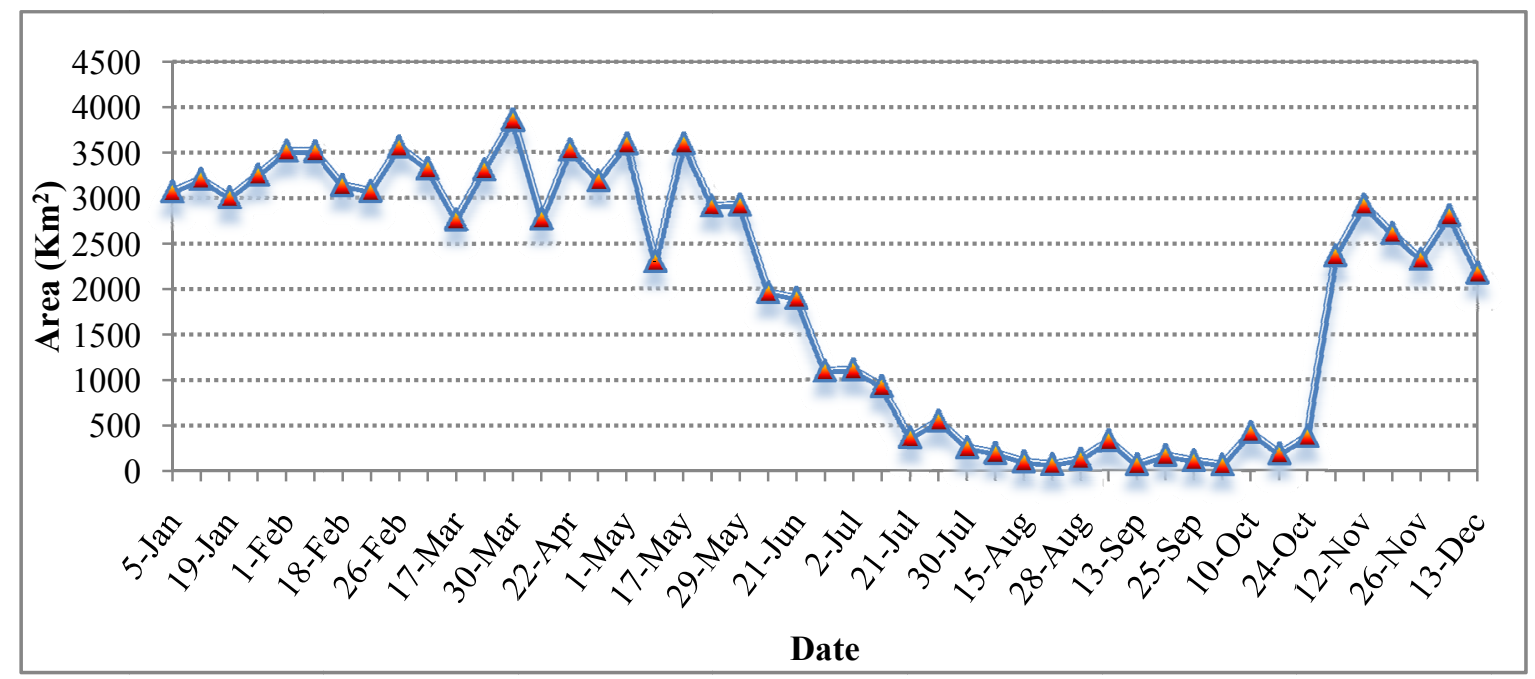

Figure 5. Snow cover extent of Astore River Basin in year 2009

Similarly, for the year of 2009 the maximum snow covered area was found for January, February and March with area $3258.36 \mathrm{Km}^{2}$ (15078 pixels), $3561.76 \mathrm{Km}^{2}$ (16482 pixels) and $3858.46 \mathrm{Km}^{2}$ (17855 pixels) respectively. Whereas the minimum snow covered extentwas found for the months of August $75.85 \mathrm{Km}^{2}(351$ pixels) and September $70.88 \mathrm{Km}^{2}$ (328 pixels). A research also presented same result, snow area extent increases particularly in the months of January and February and get its minimum value in the month of August in Northern Areas of Pakistan (Dahri, Ahmad, Leach, \& Ahmad, 2011). Similar results were also reported in by Furrukh and Ghulam (2010) supporting the fact that conducive climatic condition result in increase of snow cover. Shresthaand Joshi (2009) also reported high snow cover extent in winters and springs and low in summers. 
Table 1 presented the monthly average value of snow cover of Astore river basin and $\%$ snow cover change for both the years. There was more fluctuation in average monthly snow cover in the year of 2008 in comparison with 2009.

Table1.Monthly \% change and monthly average in Snow cover extent for years 2008 and 2009

\begin{tabular}{lrrrr}
\hline & \multicolumn{4}{c}{ Snow Cover $\left(\mathbf{K m}^{2}\right)$} \\
\cline { 2 - 5 } Month & $\mathbf{2 0 0 8}$ & $\mathbf{2 0 0 9}$ & Average & \% Change \\
\hline January & 3439 & 3139 & 3289 & -8.72 \\
February & 3546 & 3365 & 3455.5 & -5.10 \\
March & 3300 & 3316 & 3308 & 0.48 \\
April & 3235 & 3166 & 3200.5 & -2.13 \\
May & 2585 & 3071 & 2828 & 18.80 \\
June & 647 & 1657 & 1152 & 156.11 \\
July & 87 & 648 & 367.5 & 644.83 \\
August & 49 & 130 & 89.5 & 165.31 \\
September & 189 & 174 & 181.5 & -7.94 \\
October & 978 & 687 & 832.5 & -29.75 \\
November & 1752 & 2624 & 2188 & 49.77 \\
December & 2257 & 2498 & 2377.5 & 10.68 \\
Total & 1839 & 2040 & 1939.13 & 10.93 \\
\hline
\end{tabular}

\subsection{Correlation between Snow Cover and Climatic Variables}

Bi-variable correlation analysis of snow cover extent in Astore in relation with the independent climatic variables i.e. maximum and minimum temperature and precipitation described in Table 2.

Table 2. Correlation coefficients for different parameters

\begin{tabular}{|c|c|c|c|c|c|}
\hline S.No. & Variables & Snow Cover & Max Temperature & Min Temperature & Precipitation \\
\hline \multirow[b]{2}{*}{1} & \multirow{2}{*}{ Snow Cover } & & $-0.784 * *$ & $-0.767 * *$ & 0.561 \\
\hline & & 1 & 0.003 & 0.004 & 0.058 \\
\hline \multirow[b]{2}{*}{2} & \multirow{2}{*}{ Max Temperature } & & & $0.997 * *$ & -0.540 \\
\hline & & & 1 & 0.000 & 0.070 \\
\hline \multirow[b]{2}{*}{3} & \multirow{2}{*}{ Min Temperature } & & & & -0.499 \\
\hline & & & & 1 & 0.098 \\
\hline 4 & Precipitation & & & & 1 \\
\hline
\end{tabular}

$* * P<0.01$

\subsubsection{Maximum Temperature}

As the summer season starts the rising temperature causes the snow to melt down. It was clearly shown in the correlation curve Figures 6 and 7 as temperature increased, snow cover extent decreased. 


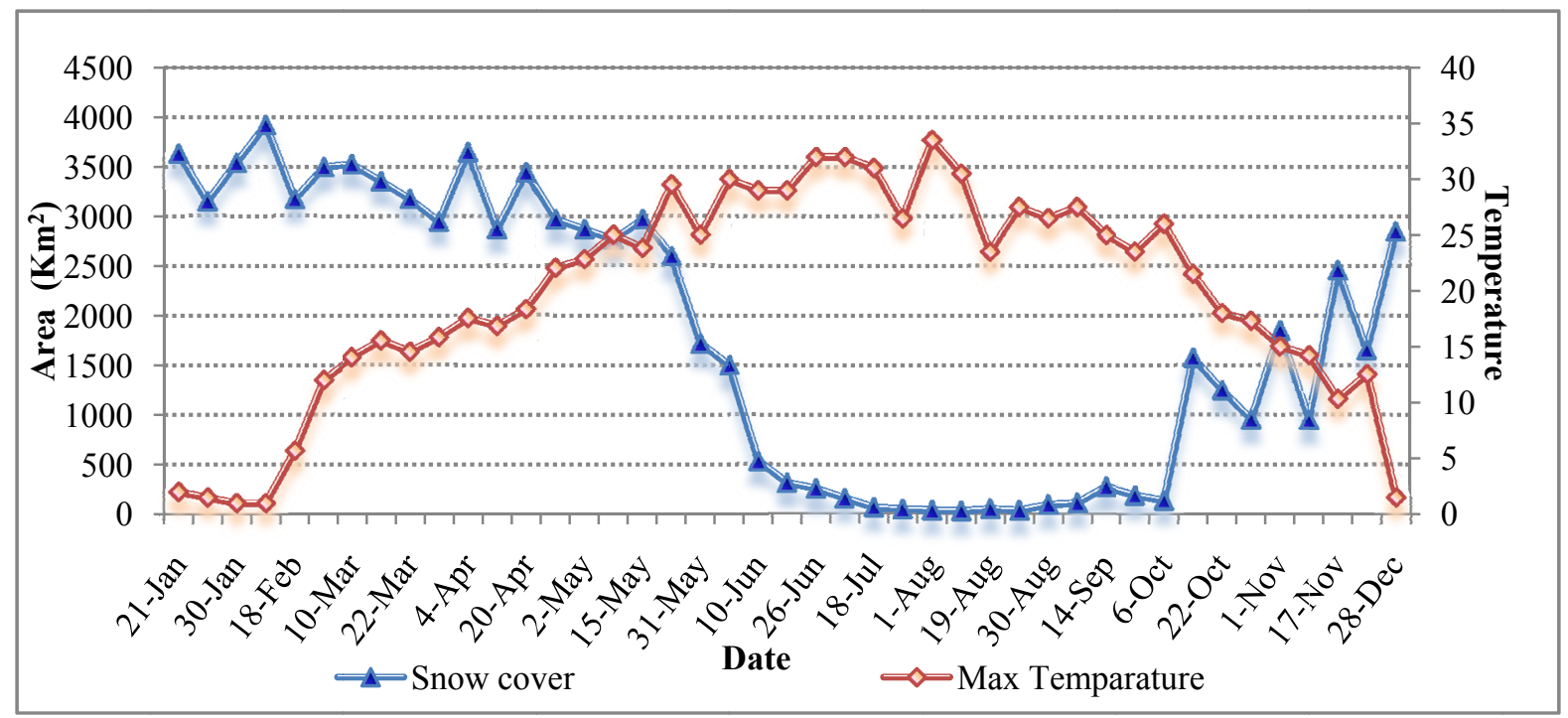

Figure 6. Fluctuations in snow cover extents of Astore for 2008 with rise in the maximum temperature

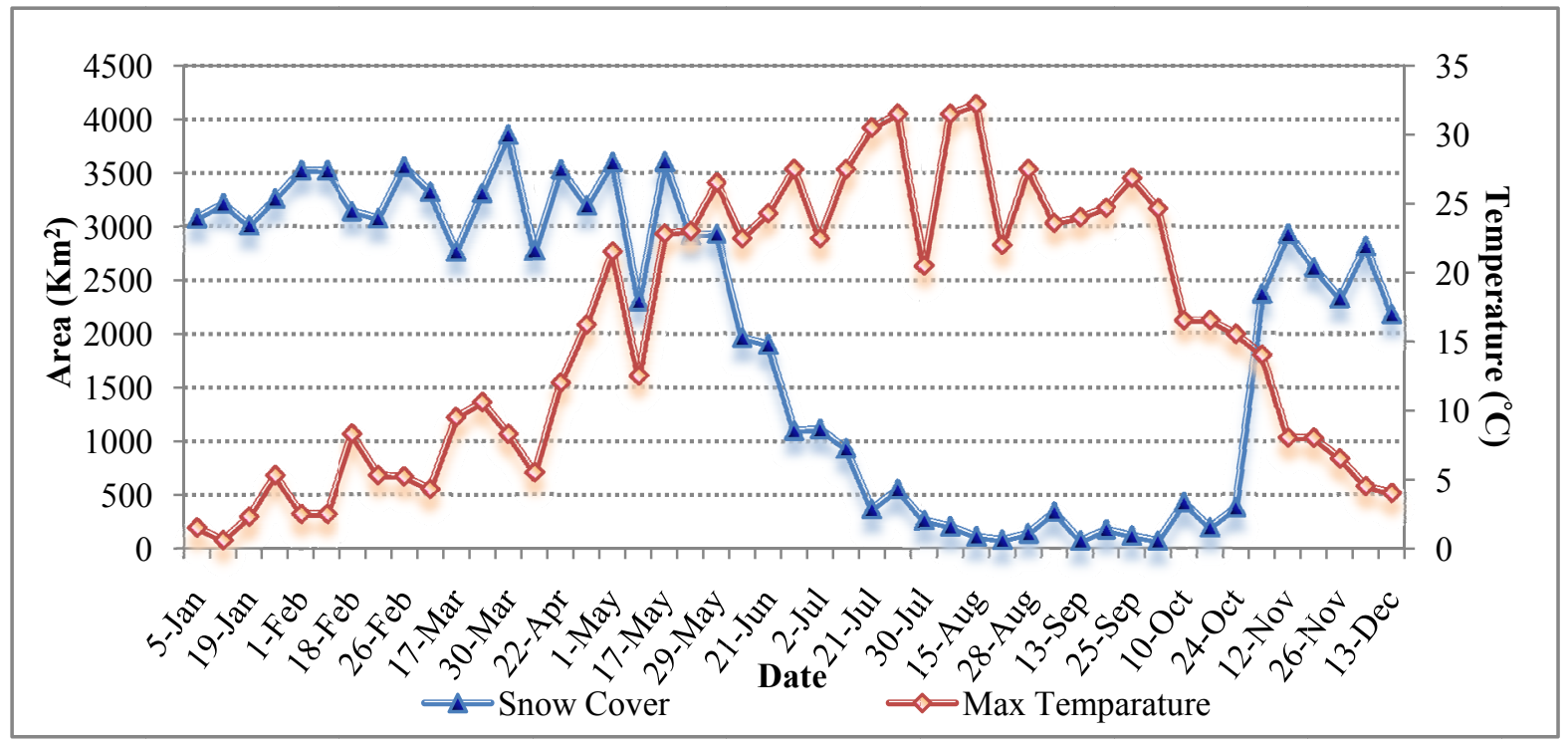

Figure 7. Fluctuations in snow cover extents of Astore for 2009 with rise in maximum temperature

The correlation coefficient between snow cover and maximum temperature was found to -0.784 (0.003) for both the year as shown in Table 2. There was a significant negative correlation between snow covered area and maximum temperatures. As the maximum temperature of Astore catchment increase it results in the decline of snow area extent which was confirmed by results, furthermore identical results were reported previously by Bednorz (2004), Xu et al. (2009) and Tahir, Chevallier, Arnaud and Ahmad (2011a).

\subsubsection{Minimum Temperature}

In summer season with the increase in the daily maximum temperature there was alsofoundan increase in the daily minimum temperatures. This rise in minimum temperature also accelerates the melting of snow cover at high rate as shown in Figures 8 and 9. 


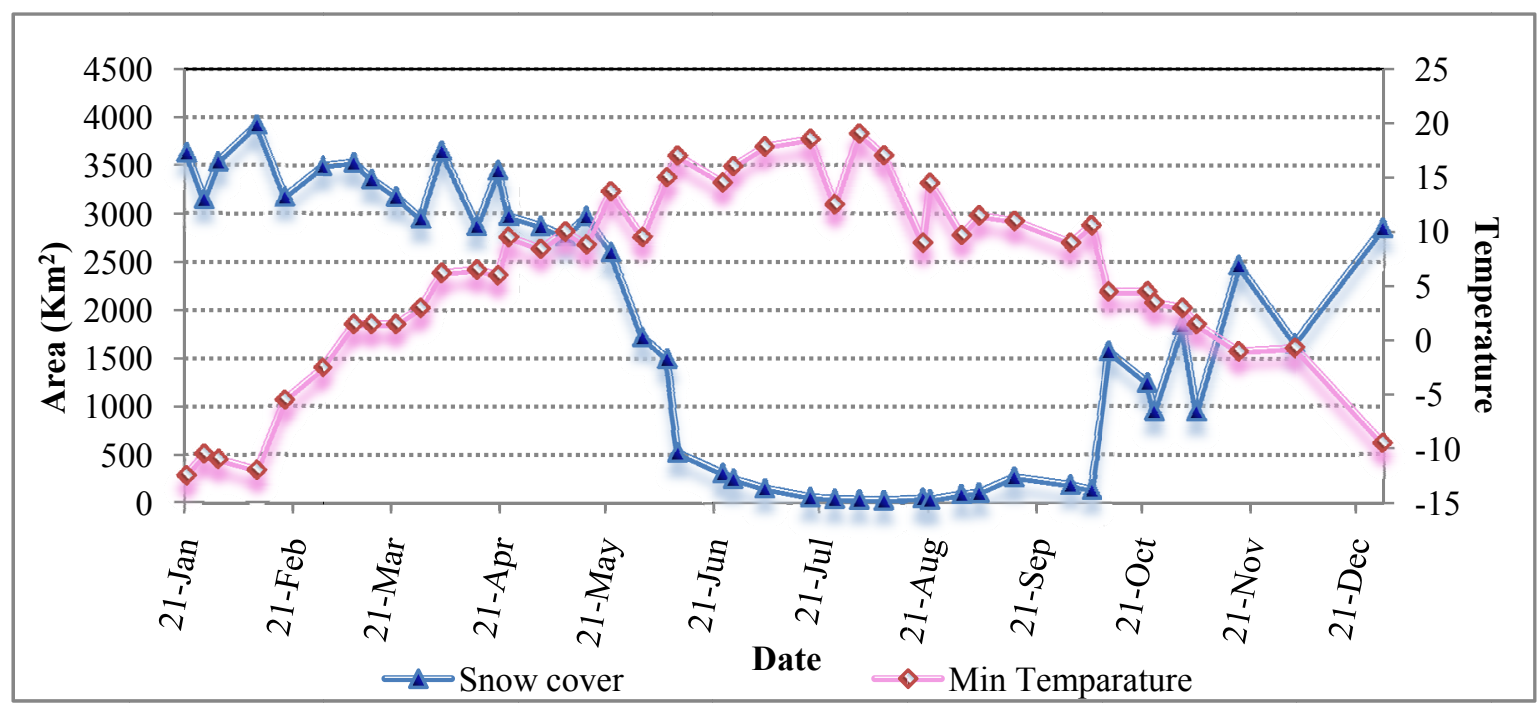

Figure 8. Fluctuation in snow covered area of Astore for 2008 with the rise and fall in minimum temperatures

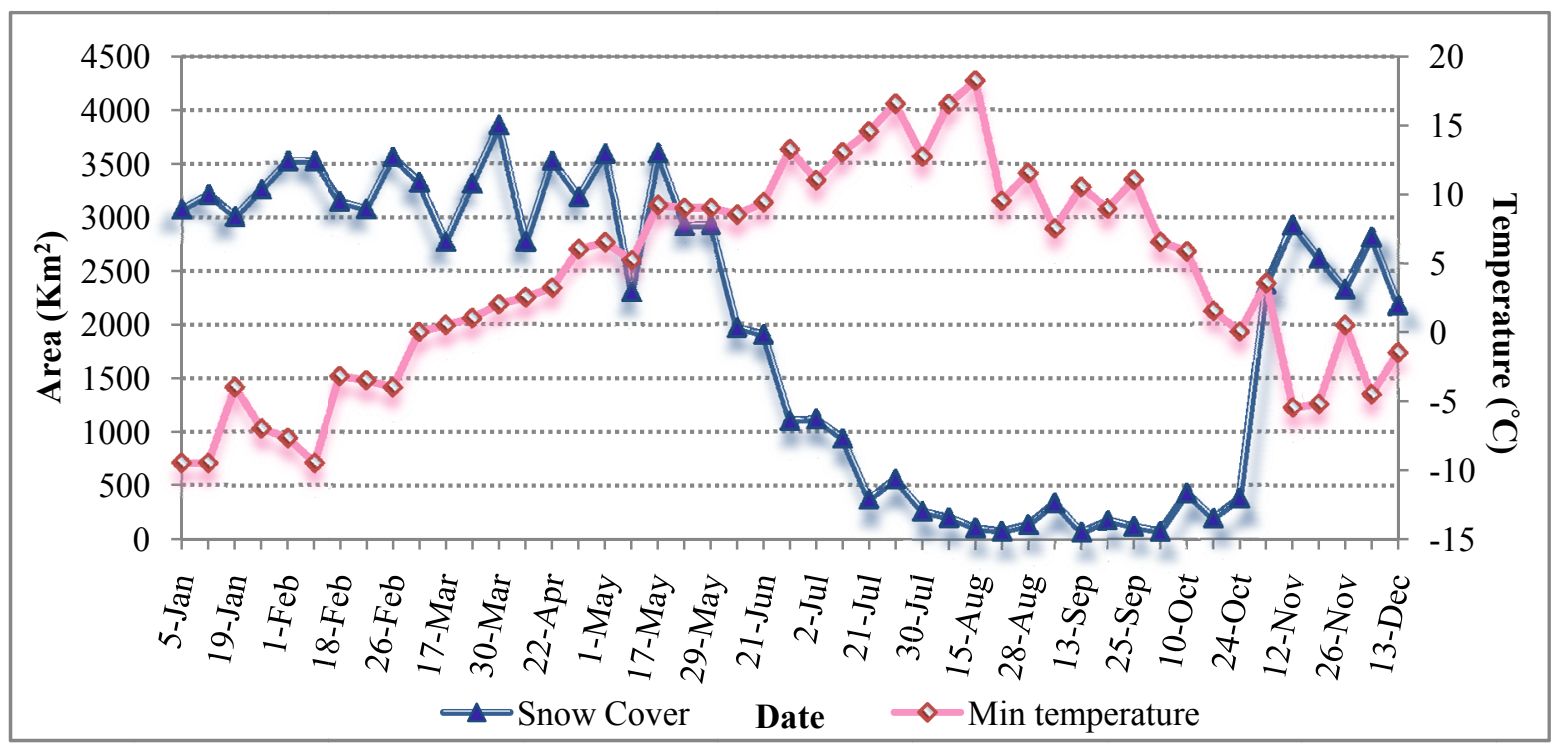

Figure 9. Fluctuation in snow covered area of Astore for 2009 with the rise and fall in minimum temperature

The observed correlation coefficient between snow cover and minimum temperature was $-0.767(0.004)$ for both the years as shown in Table 2. Correlation coefficient was showing a significant negative correlation between snow cover and minimum temperature.Similar correlation was found previously by Chaoimh (1998) and Bednorz (2004) for European snow covered areas and temperature. Xu et al. (2009) also reported a relationship of temperature with snow cover extent in Tarim river basin, northwestern China

\subsubsection{Precipitation}

Precipitation can take place in many forms like hail, snow and rain. When precipitation falls in form of snow it accumulates to build up snow cover. As precipitation increases snow cover also increases as shown in Figures 10 and 11 . 


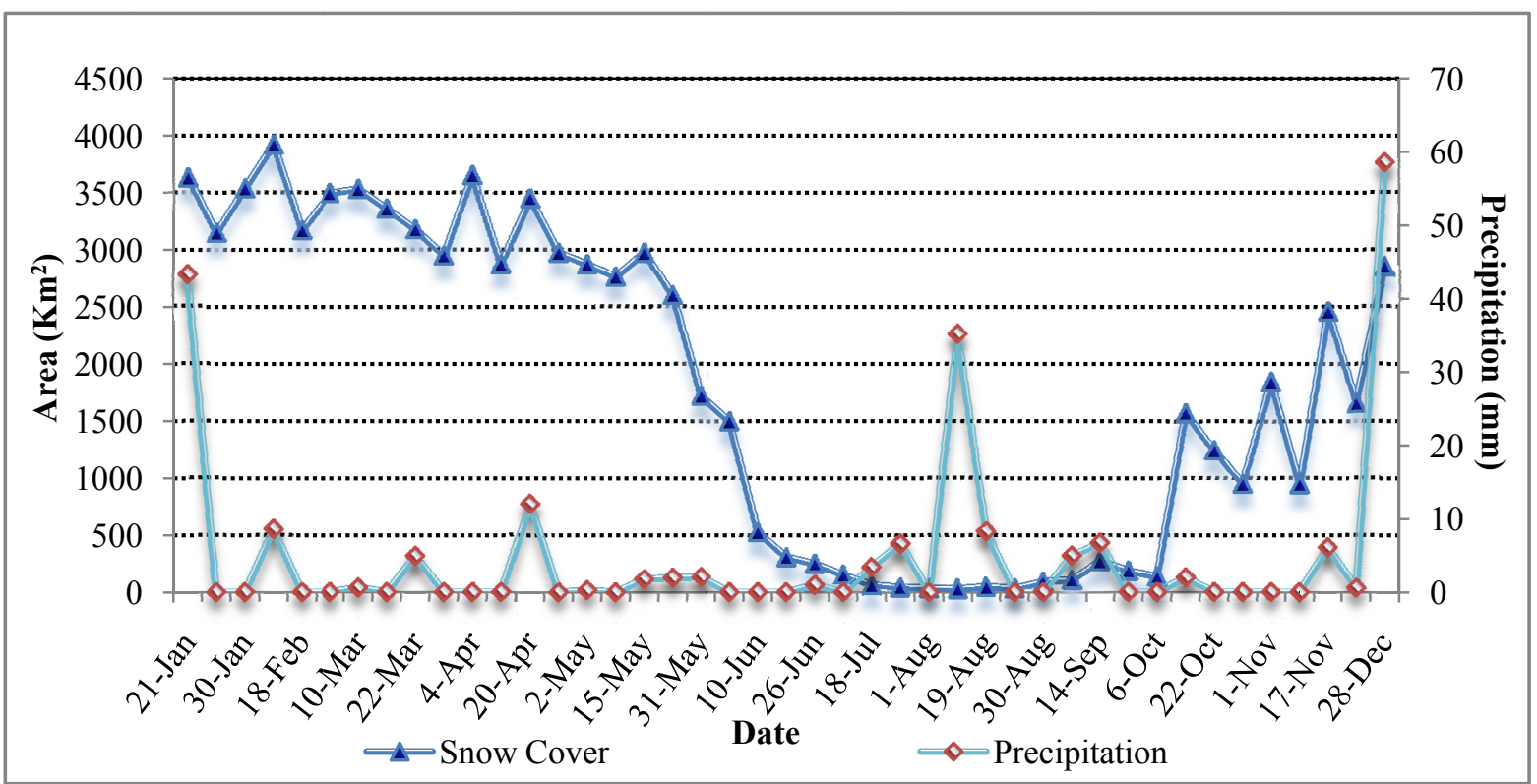

Figure 10. Variation in snow cover extents of Astore with precipitation for 2008

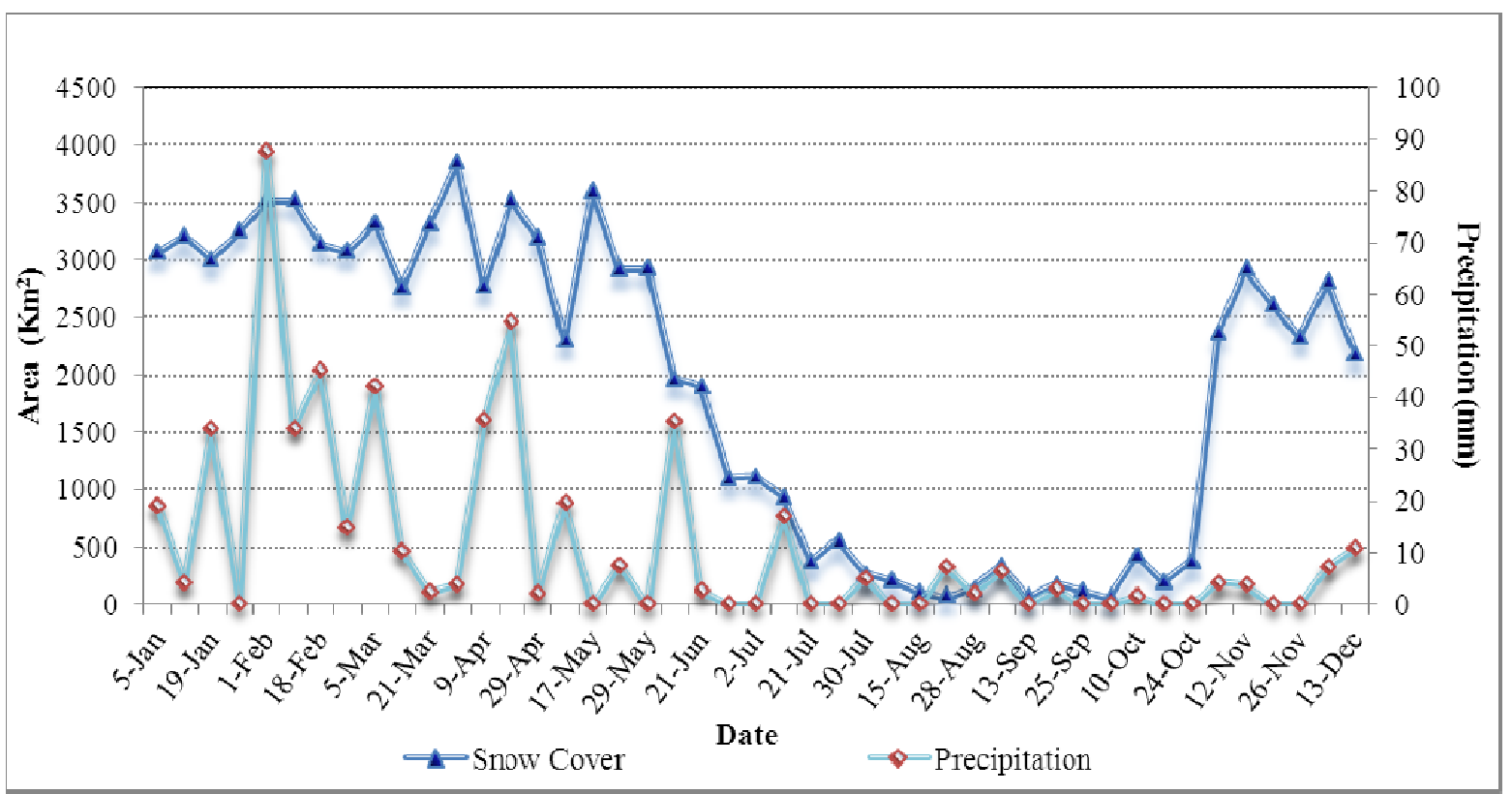

Figure 11. Variations in snow cover extents of Astore with precipitation for 2009

In the months of January and February, precipitation in form of snow results in the growth of snow cover extents. The Correlation coefficient for snow and precipitation was $0.561(0.058)$ as shown in Table 2. Hence, there exit a positive non-significant correlation between snow cover and precipitation. An increase in the amount of winter precipitation (January and February) leads to the growth of snow covered area as reported previously by Bednorz (2004), Wu and Kirtman (2007) and Tahir, Chevallier, Arnaud, Neppel and Ahmad (2011b).

\subsection{Regression Analysis}

The data were analyzed by multiple linear regression model with snow cover as the dependent variable and maximum, minimum temperatures and precipitation as independent variables. 
Table 3. Multiple linear regression analysis

\begin{tabular}{|c|c|c|c|c|c|}
\hline \multicolumn{6}{|l|}{ Coefficients(a) } \\
\hline \multirow[t]{2}{*}{ Model } & Unstandardize & Coefficients & Standardized Coefficients & $\mathbf{t}$ & Sig. \\
\hline & $\mathrm{B}$ & Std. Error & Beta & & \\
\hline (Constant) & 7842.05 & 6821.25 & & 1.15 & 0.28 \\
\hline Max Temperature & -495.65 & 579.66 & -3.41 & -0.86 & 0.42 \\
\hline Min Temperature & 459.89 & 670.52 & 2.65 & 0.69 & 0.51 \\
\hline Precipitation & 1.20 & 8.34 & 0.05 & 0.14 & 0.89 \\
\hline
\end{tabular}

$$
\mathrm{Y}=(-495.65) \mathrm{X}_{1}+(459.89) \mathrm{X}_{2}+(1.2) \mathrm{X}_{3}+7842.05
$$

$\mathrm{Y}=$ Snow cover, $\mathrm{X}_{1}=$ Maximum temperature, $\mathrm{X}_{2}=$ Minimum temperature, $\mathrm{X}_{3}=$ Precipitation

This analysis indicated that $66 \%\left(\mathrm{R}^{2}=0.661\right)$ of snow cover was dependent on the climatic variables. Regression Equation 2 can be used to predict the future snow cover in the study area under different climatic scenarios.

\section{Conclusion}

Remote sensing is a very helpful technique for acquiring information about an object or phenomenon and also for processing the gathered information. Remote areas which are not easily accessible, their monitoring can be done by using RS techniques and GIS application. As conventional methods are not very handy in calculating snow cover extents of Northern Areas (Astore) of Pakistan, therefore satellite data was used. Total 90 temporal MODIS satellite images have been selected for 2008 and 2009 to estimate snow cover of Astore river basin and its correlation with different meteorological parameters. By using different RS techniques snow covered extent was calculated. It is clear from the graphs that with the ascending maximum temperatures and minimum temperatures, snow cover deplete due to melting. Hence, there is a negative correlation exist between snow cover and maximum and minimum temperatures. Precipitation in form of snow has a positive effect on snow cover, as precipitation increases, snow cover extents also increases thus it is presenting a positive correlation. Climatic fluctuations cause's variations in the amount snow melt runoff leading to decrease or increase in snow cover extents. Conducive climatic conditions like low maximum and minimum temperature and high precipitation rate support buildup of snow and vice versa. Consequently it was concluded that meteorological parameter influences the rate of precipitation in form of snow which leads to varying distribution of snow over the Astore river basin in different months of the year.

\section{References}

Akhtar, M., Ahmad, N., \& Booij, M. J. (2008).The impact of climate change on the water resources of Hindukush-Karakorum-Himalaya region under different glacier coverage scenarios. Journal of Hydrology, 355, 148-163. http://dx.doi.org/10.1016/j.jhydrol.2008.03.015

Bednorz, E. (2004). Snow cover in Eastern Europe in relation to temperature, precipitation and circulation. International Journal of Climatology, 24, 591-601. http://dx.doi.org/10.1002/joc.1014

Chaoimh, U. N. (1998). European snow cover and its influence on spring and summer temperatures. The Geographical Journal, 164(1), 41-54.

Dahri, Z. H., Ahmad, B., Leach, J. H., \& Ahmad, S. (2011). Satellite-Based snow cover distribution and associated snowmelt runoff modeling in Swat River Basin of Pakistan. Pakistan Academy of Science, 48(1), 19-32.

Furrukh, B., \& Ghulam, R. (2010). Estimation of average snow cover over Northern Pakistan. Pakistan Journal of Meteorology, 7(13), 63-69.

Hall, D. K., Riggs, G. A., \& Salomonson, V. V. (1995). Development of methods for mapping global snow cover using Moderate Resolution Imaging Spectrometer data. Remote Sensing of Environment, 54, 127-140. http://dx.doi.org/10.1016/0034-4257(95)00137-P 
Hewitt, K., Wake, C. P., Young, G. J., \& David, C. (1989). Hydrological investigations at Biafo Glacier, Karakoram Himalaya: an important source of water for the Indus River. Annals of Glaciology, 13, 103-108. http://dx.doi.org/10.1016/j.jhydrol.2011.08.035

Lopez, P., Sirguey, P., Arnaud, Y., Pouyaud, B., \& Chevallier, P. (2008).Snow cover monitoring in the Northern Patagonia Ice field using MODIS satellite images (2000-2006). Global and Planetary Change, 61(3-4), 103-116. http://dx.doi.org/10.1016/j.gloplacha.2007.07.005

Nabi, G., Latif, M., Habib-ur-Rehman, \& Azhar, A. H. (2011). The role of environmental parameter (degree day) of snow melt runoff simulation. Soil and Environment, 30(1), 82-87

Peng, S., Piao, S., Ciais, P., Fang, J., \& Wang, X. (2010). Change in winter snow depth and its impacts on vegetation in China. Global Change Biology, 16(11), 3004-3013. http://dx.doi.org/10.1111/j.1365-2486.2010.02210.x

Rasul, G., Chudhry, Q. Z., Mahmood, A., Hyder, K. W., \& Dahe, Q. (2011). Glaciers and glacial lakes under changing Climate in Pakistan. Pakistan Journal of Meteorology, 8(15), 1-8.

Shrestha, A. B., \& Joshi, S. P. (2009). Snow cover and glacier change study in Nepalese Himalaya using Remote Sensing and Geographic Information System. Journal of Hydrology and Meteorology, 29(1), 26-36. http://dx.doi.org/10.3126/jhm.v6i1.5481

Snow and Ice Hydrology Project. (1990). Snow and Ice Hydrology Project, Upper Indus Basin, Overall.Report, WAPDA- IDRC Wilfrid Laurier University, 179.

Tahir, A. A., Chevallier, P., Arnaud, Y., \& Ahmad, B. (2011a). Snow cover dynamics and hydrological regime of the Hunza River basin, Karakoram Range, Northern Pakistan. Hydrology and Earth System Sciences, 15, 2275-2290. http://dx.doi.org/10.5194/hess-15-2275-2011

Tahir, A. A., Chevallier, P., Arnaud, Y., Neppel, L., \& Ahmad, B. (2011b). Modeling snowmelt-runoff under climate scenarios in the Hunza River basin, Karakoram Range, Northern Pakistan. Journal of Hydrology, 409, 104-117. http://dx.doi.org/10.1016/j.jhydrol.2011.08.035

Wu, R., \& Kirtman, B. P. (2007). Observed Relationship of spring and summer East Asian rainfall with winter and spring Eurasian Snow. Journal of Climate, 20, 1285-1304. http://dx.doi.org/10.1175/JCLI4068.1

Xu, C., Chen, Y., Hamid, Y., Tashpolat, T., Chen, Y., Ge, H., \& Li, W. (2009). Long-term change of seasonal snow cover and its effects on river runoff in the TarimRiverbasin, northwestern China. Hydrological Processes, 23(14), 2045-2055. http://dx.doi.org/10.1002/hyp.7334 